\title{
ALIENASI DAN PEMBAKUAN PERAN GENDER
}

\author{
Istiadah \\ Dosen Fakultas Humaniora dan Budaya UIN Malang
}

\begin{abstract}
ABSTRAK
The formal gender role in Indonesia is legitimized by laws, culture and religion. In family context, women's role is contructed as a secondary and a complementary role altough women, basically, play an important role for the family continuity. Furthermore, cultural legitimacy which is regulated in the marital laws puts the role of women as alienated role, from the equal position with men to inequal one, in daily practices. As a result, married women's position may be alienated in the family. This phenomena needs attention and deep disscussion from social scientists particularly those who are concerned with women issues (and moslems women) for the sake of gender equity as well as gender equility realization in Indonesia.
\end{abstract}

\section{A. Pendahuluan}

Alienasi adalah konsep sosiologis yang digunakan oleh Marx untuk menjelaskan fenomena yang berkaitan dengan hubungan buruh dengan kapitalisme. Konsep dasar Marx menyebutkan bahwa division of labor merupakan sumber alienasi. Konsep ini dikembangkan oleh feminis Marxis yang kemudian menemukan bahwa femininity yang dikonstruksi oleh masyarakat juga merupakan sumber alienasi bagi perempuan. ${ }^{1}$ Tulisan ini mencoba untuk mengupas konsep alienasi dalam kaitannya dengan pembakuan peran gender di Indonesia dengan Undang Undang Perkawinan dan dikuatkan oleh menguatnya semangat beragama (Islam) yang menegaskan wacana pembagian peran gender.

1 Foreman, A. (1977) Femininity as Alienation: Women and Family in Marxism and Psychoanalysis. London, Pluto. 


\section{B. Pembakuan peran gender di Indonesia}

Negara membakukan peran laki-laki dan perempuan dengan undang-undang. Dengan demikian, seolah-olah bila warga negara Indonesia berperan tidak sesuai dengan yang telah ditetapkan negara, maka mereka menjadi menyalahi peraturan. Dalam undang-undang perkawinan No 1 / 1974 pada bab VI mengenai hak dan kewajiban suami isteri pasal 31 ayat 3 disebutkan bahwa suami adalah kepala rumah tangga dan isteri adalah ibu rumah tangga. Pada pasal 34 ayat 1 dijelaskan bahwa suami wajib melindungi isterinya dan memberikan segala sesuatu keperluan berumah tangga sesuai dengan kemampuan. Ayat 2 meyebutkan bahwa isteri wajib mengatur urusan rumah tangga dengan sebaik-baiknya.

Tugas ibu rumah tangga yang "dibakukan" tersebut bisa dirinci menjadi lima komponen aktivitas. Pertama, melayani suami yang perinciannya terdiri dari: menyiapkan pakaian suami siap pakai, dari celana dalam, kaos dalam, kaos kaki, baju, celana, sepatu yang telah disemir, sapu tangan dan aksesoris lainnya. Kewajiban melayani suami yang tak kalah pentingnya adalah melayaninya untuk berhubungan badan dimana pun dan kapan pun suami menginginkannya. Tidak ada kata penolakan yang boleh diucapkan oleh isteri karena mereka bersikukuh memegang hadis yang artinya" Apabila isteri menolak ajakan suaminya (untuk bersenggama) maka dia akan dilaknat oleh malaikat sampai subuh".

Kedua, mengasuh dan mendidik anak yang secara rinci tugasnya sebagai berikut: memandikan (membersihkan), menyuapi, mengajaknya bermain, menidurkan dan menyusui. Bila anaknya sudah sampai usia sekolah, maka tugas ibu rumah tangga bertambah dengan mengantar dan menjemputnya ke dan dari sekolah, menemani belajar dan mengerjakan Pekerjaan Rumah (PR), mengambil rapor atau apa pun yang berhubungan dengan sekolah. Ketiga, membersihkan dan merapikan semua perlengkapan rumah tangga: menyapu, mengepel, mencuci alat dapur, mencuci baju sekaligus menyeterikan dan sebagainya. Keempat, menyediakan makanan siap santap. Rincian dari tugas ini meliputi: mengatur menu, berbelanja, memasak dan menghidangkannya di tempat makan. Tugas kelima dari seorang ibu rumah tangga adalah merawat kesehatan (lahir dan batin) seluruh anggota keluarganya; merawat anggota keluarga yang sakit, 
memijat bila diperlukan, dan menghibur mereka dari kecemasan yang mereka alami. Isteri adalah penghibur suaminya di kala penat dan lelah bekerja. Ibu adalah penghibur anaknya yang mempunyai problema kehidupan. Terutama bagi ibu yang menpunyai anak remaja, peran ini akan sangat disorot oleh masyarakat.

Karena kelima kelompok pekerjaan itu semuanya dianggap sebagai kewajiban pokok ibu rumah tangga, apabila ada yang tidak beres dalam hal-hal tersebut, serta merta ibu dijadikan kambing hitam. Misalnya, bila anak nilainya anjlok atau terlambat mengerjakan PR, anak remaja nakal atau tawuran, suami kurang semangat dalam bekerja sampai baju kantor suami kusut, secara otomatis orang akan mengatakan keteledoran ibu rumah tangga adalah sebab utamanya.

Dengan adanya rentetan panjang tugas wanita dalam rumah tangga, tentunya kita ingin tahu apa kewajiban suami? Jawabannya ternyata tidak sederhana. Pembagian yang kaku seperti itu tidak hanya menyebabkan laki-laki menuntut perempuan sedemikian rupa seperti yang kita paparkan di atas, tetapi perempuan juga mempunyai tuntutan yang panjang tentang peran laki-laki, sebagaimana yang disarikan oleh Ratu Hemas dalam bukunya Wanita Indonesia, Konsepsi dan Obsesi, sebagai berikut:

1. Pria berperan sebagai bapak atau suami dalam kehidupan rumah tangga.

2. Pria berperan sebagai pemimpin atau kepala rumah tangga.

3. Pria sebagai pengambil keputusan utama dalam rumah tangga.

4. Pria sebagai pengarah atau penunjuk jalan dalam rumah tangga.

5. Pria sebagai pencari nafkah atau pendapatan utama dalam rumah tangga.

6. Pria berperan sebagai pecinta dan partner berteman dan bercanda dalam rumah tangga.

7. Pria berperan sebagai penyambung lidah kepentingan rumah tangga dengan pihak luar.

8. Pria sebagai pendidik dan penyantun dalam rumah tangga.

9. Pria berperan sebagai motor penggerak jalannya rumah tangga sekaligus berfungsi sebagai mekanisme atau tukang memperbaiki bila terjadi kerusakan dalam roda rumah tangga.

10. Pria berperan sebagai pendidik atau pengajar bagi anggota keluarga di rumah tangga.

11. Pria berperan sebagi pencari jalan keluar dalam kemelut dan krisis di dalam rumah tangga.

12. Pria bergerak sebagai pihak yang berinisiatif dan progres dalam hubungan kehidupan rumah tangga.

13. Pria berperan sebagai penjaga gawang atau pertahanan yang utama dan terakhir dalam perkembangan pergerakan kehidupan rumah tangga. 
Dari perincian tugas laki-laki dan perempuan di atas, jelas sekali bahwa laki-laki memiliki peran yang dominan dalam keluarga. Ia bukan saja pencari nafkah utama, tapi juga sebagai pemimpin dengan segala tugas dan kewenangannya yang sekaligus juga mendapat hak-hak istimewa dan penghargaan yang lebih dari masyarakat. Sementara perempuan hanyalah pendamping suami yang tugasnya 'hanya' ditempatkan sekadar mengelola harta dan anak-anak suaminya, yang berarti keberadaan perempuan bukanlah primer, tapi sekunder (kedua) dan komplementer (sebagai pelengkap saja).

Lebih parah lagi ternyata tugas panjang suami yang tersebut di atas lebih merupakan harapan perempuan saja karena tugas suami yang bisa dilihat sehari-hari hanyalah tugas menjadi pencari nafkah utama, sedang tugas menjadi pelindung, pemimpin dan pencari jalan keluar kemelut rumah tangga adalah hal yang sulit dilihat. Apalagi kenyataannya perempuan sering harus berjuang keras dan mengalah untuk menyelesaikan kemelut rumah tangga dan semakin banyak pula isteri yang menjadi pencari nafkah bahkan menjadi pencari nafkah utama. Sedangkan tugas menjadi ibu rumah tangga hasilnya sangat mudah dilihat dan harus dikerjakan secara rutin. Sehari saja isteri tidak mengerjakan tugas kerumahtanggaan akibatnya bisa fatal, rumah tak karuan, anak tidak makan dan tidak mandi, baju dan perabotan kotor semua. Pendek kata, tugas ibu rumah tangga tak mungkin ditinggalkan walau hanya sekejap, sedangkan tugas suami tidak memerlukan tanggung jawab yang mendetail. Mencari nafkah semampunya bukanlah hal yang terlalu rumit apabila seseorang telah mempunyai pekerjaan tetap. Sehingga sering terlihat bahwa bila suami pulang bekerja mendapatkan pelayanan isteri, namun isteri yang menjadi pencari nafkah utama bila pulang ke rumah masih harus melayani suami dan seluruh anggota keluarga.

\section{Konsep Alienasi}

M. Francis Abraham menyebut bahwa awal mula perkembangan alienasi bisa dirunut ulang dari idealisme German, filasafat idealis yang dipelopori oleh Hegel. Namun Marx telah membuat konsep alienasi menjadi alat yang sangat penting untuk melihat gejala masyarakat. Menurut Marx, sejarah manusia bukan hanya diwarnai oleh perjuangan kelas namun juga meningkatnya keterasingan (alienasi) manusia. Marx 
berpendapat bahwa keterasingan telah marasuki setiap institusi, termasuk agama, ekonomi dan negara. Bagi Marx, buruh terasing dalam empat aspek. Pertama, buruh terasing dari produk yang dia hasilkan. Kedua, buruh terasing dari proses produksi. Ketiga, buruh terasing dari dirinya sendiri. Keempat, buruh terasing dari teman dan komunitas manusia yang lain.

Alienasi nampak bukan hanya dari hasil produk tetapi juga dari proses menghasilkan produk, dalam aktivitas itu sendiri. Marx menulis "jika produk merupakan alienasi, produksi itu sendiri pasti merupakann alienasi". 2

Pekerja adalah korban dari eksploitasi borjuis. Pekerja telah didevaluasi bukan sebagai manusia (yang mempunyai keutuhan sebagai manusia yang berkeinginan, kreatif, dsb) tetapi menjadi komoditi. Dalam hal ini Abraham memberikan penjelasan bahwa "pekerja menghabiskan hidupnya dan menghasilkan sesuatu bukan untuk dirinya sediri, tetapi untuk kekuasaan yang memanipulasi dirinya. Pekerja mungkin menghasilkan keindahan, kemewahan dan kecerdasan (untuk orang yang mempekerjakan), namun yang dirasakan oleh buruh adalah sebaliknya. ${ }^{3}$

Alienasi juga merupakan hilangnya kontrol individu atas kegiatan kreatifnya sendiri dan produksi yang dihasilkannya. Pekerjaan dialami sebagai suatu keharusan untuk sekadar bertahan hidup dan tidak sebagai alat bagi manusia untuk mengembangkan atau menyatakan kemampuannya yang kreatif. Individu merasa tidak mampu untuk mengembangkan diri, dalam pengertian yang luas, melalui kegiatan produksinya. ${ }^{4}$

Yang perlu digarisbawahi di sini adalah hilangnya kontrol atas kegiatan yang dijalankan. Para buruh, dalam konteks kapitalis, bekerja untuk menghasilkan produk bukan untuk memenuhi kebutuhan mereka sendiri, namun untuk komoditi yang ditukar dengan uang dalam sistem pasar yang impersonal

Marx mengatakan :

Buruh menempatkan hidupnya dalam obyek, dan kemudian hidupnya tidak lagi menjadi miliknya tetapi milik obyek itu. Kemudian semakin besar kegiatannya, semakin kurang yang dimilikinya. Lalu semakin besar produk itu, semakin besar

2 Abraham, F.M. (1982) Modern Sociological Theory: An Introduction. London, Oxford University Press.

3 ibid

${ }^{4}$ Lawang, R.M.Z. (1986) Teori Sosiologi Klasik dan Modern. Terj. Jakarta, PT Gramedia. 
pula ia dimiskinkan. Alienasi buruh dalam produknya tidak hanya berarti bahwa tenaganya menjadi suatu obyek, yang mengandaikan suatu eksistensi eksternal, melainkan bahwa obyek itu berada secara independen, di luar dirinya, dan asing baginya, dan menentang dia sebagai suatu kekuatan yang otonom. Kehidupan yang sudah dia berikan pada obyek itu berbalik melawan dia sebagai suatu kekuatan yang bermusuhan ${ }^{5}$

Marx dan pengikutnya berpendapat bahwa alienasi melekat pada setiap sistem pembagian kerja dan pemilikan pribadi, tetapi yang paling ekstrem bentuknya adalah kapitalisme. Dalam kapitalisme mekanisme pasar bersifat impersonal. Hal ini berarti menurunkan kodrat manusia hanya menjadi komoditi, yang ini jelas bertentangan dengan hukum alam dan kebebasan manusia.

Marx dalam bukunya alienated labour lebih gamblang menjelaskan adanya alienasi dengan pertanyaan "kalau produk buruh menjadi asing bagi saya dan mengkonfrontasi saya sebagai suatu kekuatan asing, siapa yang memilikinya ? kalau kegiatan saya sendiri bukan milik saya tetapi sebagai suatu kegiatan yang asing dan memaksa lalu siapa yang memilikinya? Bukan diri saya, tetapi yang lain di luar diri saya. Dan siapa yang lain itu? Jawaban yang jelas adalah bahwa yang lain itu adalah majikan kapitalis.

Dalam makalah ini saya meminjam analisis Schacht (dalam Abraham) yang membagi bahasan tentang alienasi menjadi empat sub bab.

\section{Alienasi dan "Other"}

Dalam perspektif ini alienasi mengandung arti sebagai berikut :

(a) kesepian yaitu kurangnya support tehadap hubungan yang primer, isolasi sosial, dam tiadanya ketertarikan interpersonal.

(b) Kurangnya solidaritas, yaitu tidak adanya rasa memiliki, merasa tidak bisa berbagi, pengucilan dari partisipasi sosial dan kultural, kurangnya identifikasi dengan pandangan, rasa, dan interes masyarakat.

(c) Ketidakpuasan dalam hubungan sosial.

\section{Alienasi dan Kerja}

Hal ini mencakup :

(a) Kurangnya kepuasan kerja, yaitu perasaan kecewa terhadap posisi dan pekerjaan

\footnotetext{
${ }^{5}$ ibid
} 
(b) Kurangnya penghargaan instrinsik terhadap kerja, yaitu kerja hanya untuk hidup bukan bekerja berarti mendapatkan penghargaan.

(c) Kurangnya kontrol, kebermaknaan, dan ekspresi diri dalam pekerjaan - tiadanya kontrol personal terhadap hasil kerja, proses produksi dan aktivitas manajerial; ketidakbermaknaan dari kerja karena adanya patokan yang ekstrem dan kurangnya kesempatan untuk ekpresi diri.

\section{III.Alienasi, Kejadian, dan Struktur}

(a) Perasaan ketidakberdayaan, yaitu ketidakmampuan untuk mempengaruhi kejadian sosio politik, perasaan tidak mampu untuk menyelesaikan permaslahan kekinian.

(b) Kesalahan dari ketidakmampuan - ide bahwa seseorang bukan karena dia merasa tidak berdaya tetapi karena ketidakberdayaan tersebut illegitimate (tidak syah); yaitu perasaan bahwa seseorang telah mengingkari haknya untuk "mengontrol".

(c) Distrust (ketidakpercayaan) dan Apaty. Mereka tidak percaya lagi pada pimpinan politik atau political apathy

(d) Ketidakmampuan memahami kejadian - suatu perasaan ketidakbermakanaan dari keseluruhan tujuan, ketidakmampuan untuk memahami kejadian yang sebenarnya merupakan penentu kebahagiaannya.

(e) Pilihan yang tanpa arti-bukan ketidakbermaknaan atau perasaan ketidakberdayaan itu sendiri yang dimaksud tetapi lebih pada kesadaran bahwa seseorang harus memilih dari sejumlah alternatif tetapi di dalamnya tidak ada perbedaan perasaan atau perasaan bahwa mereka tidak mempunyai cukup informasi untuk mencapai pilihan yang cerdas.

\section{IV.Alienasi, Kultur dan Masyarakat.}

(a) Diasosiasi dari kultur populer--- yaitu adanya penolakan individu terhadap standar kultural yang umum.

(b) Diasosiasi dari nilai masyarakat ---- kurangnya identifikasi dari nilai fundamental dari suatu masyarakat.

(c) Penolakan terhadap norma perilaku masyarakat --- yaitu penolakan terhadap standar perilaku yang mapan.

(d) Anomie 6

Para sosiolog kemudian banyak yang mengembangkan konsep alienasi untuk melakukan penelitian tentang ada tidaknya alienasi dalam masyarakat. Yang perlu digarisbawahi adalah seseorang tidak dikatakan terasing atau mengalami alienasi kecuali memenuhi kriteria perasaan yang sesuai dengan konsep alienasi. Oleh karena itu para sosiolog mencoba membuat daftar pertanyaan yang mampu menjabarkan perasaan yang sesuai. Hal ini biasanya didapat dengan bantuan sejumlah pernyataan yang harus

\footnotetext{
${ }^{6}$ Abraham, op cit.
} 
direspon oleh subyek penelitian. Namun Schacht sendiri ragu tentang kemungkinan membuat test yang cukup sensitif untuk mengungkap perasaan yang dibutuhkan. Apalagi bila kita ingin mengembangkan test yang bebas budaya.

\section{Pembagian peran gender dan alienasi}

Setelah menengok konsep alienasi yang dikembangkan oleh sosiolog, penulis mencoba menggunakan konsep ini untuk memahami fenomena pembakuan peran gender di Indonesia yang secara spesifik membakukan pembagian peran seksual dalam keluarga menjadi sebuah hukum positif yang diundangkan. Apalagi secara konteks kultural telah terjadi revitalisasi beragama, atau dikenal dengan istilah santrinisasi birokrasi. Ada kebanggaan baru menjadi santri. ${ }^{7}$ Semangat keberagamaan yang mengental ditandai dengan maraknya fenomena jilbab dan menguatnya semangat mengembalikan peran perempuan sebagai ibu rumah tangga. Sehingga tercipta suatu image bahwa bila kau ingin dianggap menjadi muslimah yang baik kau harus menanggalkan atau menomorduakan karirmu dan kembali kerumah untuk menjadi ibu rumah tangga.

Pencitraan ini sedemikian kuat terlihat dari pemaparan media, isi khutbah atau pidato da'i kondang atau buku-buku yang populer beredar di masyarakat, baik yang dikarang oleh penulis dalam negeri maupun hasil terjemahan. Lembaga Bantuan Hukum - Asosisasi Perempuan Indonesia untuk Keadilan (LBH-APIK) melakukan penelitian tentang respon agama (Islam) terhadap Pembakuan Peran. Penelitian ini bertujuan untuk memahami sejauh mana hubungan tarik menarik antara teks dan tafsiran pengikutnya, berkenaan tentang konsep pembakuan peran. Penelitian ini dilakukan di beberapa pengadilan agama, MUI pusat, Muslimat NU dan pondok pesantren. Sedangkan media yang diteliti adalah Majalah Amanah, buku-buku Islam, ceramah agama di radio, kaset dan TV. Serta mewawancarai muballighat kondang. Hasil penelitian ini menunjukkan bahwa walaupun ada variasi pendapat tentang peran perempuan, wacana yang dominan

\footnotetext{
${ }^{7}$ Schwarz, A. (1994) A Nation in Waiting: Indonesia in the 1990s, Sydney, Alen \& 0++Unwin.
} 
adalah tetap konvensional, yaitu peran perempuan yang pertama dan utama adalah menjadi ibu rumah tangga, yang rincian tugasnya telah kita kupas pada awal tulisan ini. ${ }^{8}$

Dalam bagian ini penulis mencoba mengungkap kemungkinan adanya alienasi pada perempuan berkeluarga yang terhimpit pembakuan peran yang telah disyahkan oleh negara dan dikuatkan oleh wacana agama yang beredar di masyarakat. Penulis menggunakan konsep Schacht untuk menguraikan hal ini.

Seperti telah dibahas sebelumnya bahwa Schacht menemukan empat konsep yaitu alienasi dan "other"; alienasi dan kerja; alienasi, kejadian dan struktur; alienasi, kultur dan masyarakat.

\section{Alienasi dan "Other"}

Dalam perspektif ini, alienasi mengandung arti sebagi berikut :

(a) kesepian yaitu kurangnya support terhadap hubungan yang primer, isolasi sosial, dan tiadanya ketertarikan interpersonal. Di sini perempuan (dalam hal ini isteri) yang teralienasi merasa bahwa hubungan yang dia bina dengan suami adalah bagai hubungan dengan orang lain yang jauh, karena suami menampakkan diri sebagai bos dari pada partner.

(b) Kurangnya solidaritas, yaitu tidak adanya rasa memiliki, merasa tidak bisa berbagi, pengucilan dari partisipasi sosial dan kultural, kurangnya identifikasi dengan pandangan, rasa, dan interes masyarakat. Dunia luar sana sudah berubah sangat tajam. Kenyataannya secara global, partisipasi perempuan di dunia publik meningkat. Namun ideologi yang melingkupi kehidupan muslimah menghimpit perempuan untuk tidak bisa menikmati apa yang perempuan pada umumnya boleh menikmati, yaitu mengembangkan diri menjadi wanita karir.

(c) Ketidakpuasan dalam hubungan sosial. Akibat lebih lanjut perempuan muslimah yang ingin taat pada agama malah tidak bisa menikmati hubungan sosial yang wajar, karena empat dinding tembok rumahnya adalah lingkup ibadahnya yang utama.

${ }^{8}$ Munti, R. B. (1997) "Respon Agama (Islam)terhadap Pembakuan Peran” Penelitian tidak dipublikasikan. 


\section{Alienasi dan Kerja}

Hal ini mencakup :

(a) Kurangnya kepuasan kerja, yaitu perasaan kecewa terhadap posisi dan pekerjaan. Pekerjaan disini tentu bukan pekerjaan dalam arti umum tapi pekerjaan rumah tangga. Yang perlu dicatat bahwa dalam pembakuan peran gender semua yang berjenis kelamin perempuan suka atau tidak, harus menekuni pekerjaan sebagai ibu rumah tangga. Sehingga hal itu bukanlah sebuah pilihan tapi keharusan ideologis. Bagi yang suka hal itu tidaklah akan menimbulkan alienasi namun bagi yang tidak suka dan bukan pilihannya sama sekali, maka pembakuan pembagian peran ini tentu akan sangat mengganggu hidupnya. Bila pekerjaan tidak sesuai dengan keinginan seseorang tentu dapat dipahami bila dia merasa kurang puas. Apalagi posisi dia dalam pekerjaan ini tidak akan pernah mencapai posisi puncak karena bagaimanapun besarnya tanggung jawab yang harus dipikul ibu rumah tangga, dia hanyalah "the second sex". Dia paling tinggi akan hanya menjadi wakil kepala dalam keluarga.

(b) Kurangnya penghargaan instrinsik terhadap kerja, yaitu kerja hanya untuk hidup bukan bekerja berarti mendapatkan penghargaan. Pekerjaan menjadi ibu rumah tangga mau tidak mau harus dia kerjakan agar dia dapat memperoleh haknya yaitu mendapat nafkah dari suaminya berupa kebutuhan primernya berupa pangan, sandang dan papan. Artinya bila menjadi ibu rumah tangga bukan atas pilihan, dia melakukan pekerjaan itu hanya sekadar untuk hidup bukan untuk mengembangkan kreativitasnya. Bisa dipastikan bahwa dia tidak akan berusaha untuk melakukan pekerjaan itu sebaik mungkin kalau motivasinya hanya sekadar agar bisa survive.

(c) Kurangnya kontrol, kebermaknaan, dan ekspresi diri dalam pekerjaan - tiadanya kontrol personal terhadap hasil kerja, proses produksi dan aktivitas manajerial; ketidakbermaknaan dari kerja karena adanya patokan yang ekstrem dan kurangnya kesempatan untuk ekspresi diri. Menjadi ibu rumah tangga dan isteri, walaupun mengerjakan semua pekerjaan kerumahtanggaan, dia bukanlah manajer. Dia hanyalah pelaksana. Apabila suami (baca: boss) tidak berkenan dengan hasil 
kerja isteri (baca:pegawai), maka tak jarang sang isteri menjadi sasaran kemarahan ${ }^{9}$ Malangnya perilaku suami yang suka menganiaya isteri tidak dipandang sebagai “deviant” atau perilaku yang merusak tatanan sosial. ${ }^{10}$

Agama juga berperan menjadi alat represi bahwa isteri harus senantiasa berusaha memberikan pelayanan yang terbaik untuk suaminya. Kisah Atikah sebagai perempuan yang masuk surga pertama karena beliau selalu melayani suaminya dengan prima dan senantiasa menyediakan cambuk. Bila suaminya tidak berkenan dengan pelayanan yang diberikan dia rela dicambuk, dan oleh karena itulah dia akan menjadi perempuan yang masuk surga pertama.

Dari uraian di atas jelas bahwa perempuan bukanlah majikan dari keringatnya sendiri. Suami adalah penentu apakah hasil kerja isteri sesuai dengan standar yang ditentukan suami atau tidak. Dengan demikian isteri telah teralienasi dari keringatnya sendiri. Hal ini berarti perempuan kehilangan kebermaknaan dalam kegiatan yang dia lakukan. $^{11}$

\section{Alienasi, Kejadian, dan Struktur}

(a) Perasaan ketidakberdayaan, yaitu ketidakmampuan untuk mempengaruhi kejadian sosio-politik, perasaan tidak mampu untuk menyelesaikan permaslahan kekinian. perempuan merasa tidak mampu untuk mempengaruhi keadaan sosial yang telah memojokkannya. Perempuan merasa tidak berdaya berhadapan dengan hegemoni agama dan negara yang sedemikian kuat. Mereka merasa tidak berdaya untuk menyelesaikan masalah mereka sendiri, untuk keluar dari ideologi gender yang menyebabkan penderitaan perempuan. Mungkin inilah yang menjadi sebab organisasi seperti PKK yang dicipta dari wanita untuk wanita tidak sama sekali ingin merubah tatanan sosial yang memojokkan perempuan malah melestarikannya.

(b) Kesalahan dari ketidakmampuan - ide bahwa seseorang bukan karena dia merasa tidak berdaya tetapi karena ketidakberdayaan tersebut illegitimate (tidak

\footnotetext{
${ }^{9}$ Dobosh, E. dan Dobosh, . P. R. (1995) "Wives : The "appropriate" Victims", Victimology, Vol 2

${ }^{10}$ Pagelow, M. (1984) Family Violence. New York, Praeger.

${ }^{11}$ Gove R. W., and J. F. Tudor (1975) "Adult sex role and mental ilness" in Joan Huber Changing Women in a Changing Society, Chicago and London: The University of Chicago Press.
} 
syah); yaitu perasaan bahwa seseorang telah mengingkari haknya untuk "mengontrol”. Di sini perempuan yang sadar bahwa ideologi yang melingkupinya sebenarnya adalah salah, bahwa prempuan bukan tercipta hanya menjadi ibu rumah tangga, malah dipandang secara salah. Perempuan seharusnya menerima kodratnya sebagai perempuan yang inherent di dalamnya bertugas menjadi ibu rumah tangga. ${ }^{12}$ Di sini perempuan mengingkari haknya untuk mengontrol dirinya, bila dia sadar bahwa dia punya hak untuk mengontrol dia malah salah (baca: dipersalahkan).

(c) Distrust (ketidakercayaan) dan Apaty. Mereka tidak percaya lagi pada pimpinan politik atau political apathy. Perempuan yang teralienasi kemudian tidak lagi percaya pada pemimpin organisasi maupun politik, karena mereka tidak mau mengentaskan perempuan dari penderitaan yang menderanya. Terjadilah kemudian political apathy. Tak ada partai politik yang bisa membongkar pembakuan peran gender, tak juga pun pemimpin perempuan.

(d) Ketidakmampuan memahami kejadian - suatu perasaan ketidakbermakanaan dari keseluruhan tujuan, ketidakmampuan untuk memahami kejadian yang sebenarnya merupakan penentu kebahagiaannya. Perempuan tentu ingin hidup bahagia dan bermakna. Tetapi mereka tidak bisa menentukan sendiri jenis kebahagiaan yang harus dia raih. Banyak perempuan yang semasa lajang ceria dan bahagia. Namun setelah memasuki dunia rumah tangga harus kehilangan orientasi hidupnya sendiri, karena kehidupan yang dia jalani menjauhkan dirinya dari cita-citanya. Gove R. W., and J. F. Tudor ${ }^{13}$ dalam artikelnya "Adult sex role and mental ilness" menemukan beberapa alasan yang membuat perempuan mempunyai beban psikologis lebih berat dari laki-laki. Pertama, kebanyakan perempuan hanya mempunyai peran tunggal, sedangkan laki-laki selalu mempunyai dua peran sebagai kepala keluarga dan sebagai pekerja. Akibatnya, bila laki-laki tidak puas dengan salah satu peran bisa mengalihkan energinya ke peran yang lainnya,

${ }^{12}$ Al Bagdadi, Abdurrahman (1991) Emansipasi Adakah dalam Islam: Suatu Tinjauan Syari'at Islam tentang Kehidupan Wanita, Gema Insani Press, Jakarta, Al Jandul, Sa'id Abdul Aziz (1991) Wanita dibawah Naungan Islam. CV. Fidaus, Jakarta dan Asy-Syantuh, Khalid Ahmad (1993) Pendidikan Anak Putri dalam Keluarga Muslim. Pustaka Al-Kautsar, Jakarta.

${ }^{13}$ Gove R.W., op.cit 
sedangkan perempuan bila tidak puas dengan kehidupan keluarganya dia tidak punya alternatif untuk mendapatkan prestise dan kepuasan. Kedua, menurut penelitian yang dilakukan Gove dan Tudor banyak perempuan yang menyatakan bahwa pekerjaan rumah tangga dan pengasuhan anak membuat mereka frustrasi. Menjadi ibu rumah tangga tidak memerlukan keahlian khusus yang artinya semua orang baik yang terdidik maupun tidak secara relatif bisa melakukannya. Terlebih lagi karena prestise ibu rumah tangga rendah, bukan saja di mata masyarakat tetapi juga di mata suami. Buktinya banyak suami yang menyepelekan isterinya bahkan berlaku keras bila pelayanannya kurang pas dari ukuran yang diinginkannya. Ketiga, pekerjaan rumah tangga kurang terstruktur dan tidak jelas ukurannya, dan sering tumpang tindih. Terlebih ibu rumah tangga yang mempunyai anak balita, pekerjaan sering tertunda dan terbengkelai karena harus mendahulukan pelayanan pada anaknya yang merengek meminta sesuatu. Pekerjaan yang tidak terorganisir dengan baik sangat mungkin menimbulkan stress. Keempat, perempuan terutama yang dari kelas bawah banyak yang terpaksa bekerja mencari nafkah. Sedangkan perempuan kelas menengah banyak yang bekerja demi aktualisasi diri. Namun yang menjadi masalah adalah walaupun bekerja di luar rumah, ternyata bukan berarti perempuan lebih ringan beban fisik dan mentalnya karena ideologimys tetap bahwa isteri yang bekerja seolah hanya mencari penghasilan tambahan, walaupun kenyataannya dia adalah pencari nafkah utama. Akibatnya banyak perusahaan yang tidak memberikan imbalan yang sama antara laki-laki dan perempuan pada posisi yang sama. Lebih parah lagi, Rahardjo ${ }^{14}$ menemukan bahwa bagi pemberi kerja perempuan adalah pilihan terakhir untuk mendapatkan pekerjaan, namun pilihan pertama untuk dipecat "women are the last hired and the first fired"

(e) Pilihan yang tanpa arti - bukan ketidakbermaknaan atau perasaan ketidakberdayaan itu sendiri yang dimaksud tetapi lebih pada kesadaran bahwa seseorang harus memilih dari sejumlah alternatif tetapi di dalamnya tidak ada

\footnotetext{
${ }^{14}$ Rahardjo Y. et al (1986) Wanita Kota jakarta: Kehidupan Keluarga dan Keluarga Berencana, Yogyakarta : Gajah Mada University Press
} 
perbedaan perasaan atau perasaan bahwa mereka tidak mempunyai cukup informasi untuk mencapai pilihan yang cerdas. Dalam konteks negara modern Indonesia seolah perempuan mempunyai beberapa alternatif pilihan. Namun bila dilihat lebih teliti pilihan - pilihan tersebut bagai simalakama. Pilihan agar tetap bebas menentuan nasib sendiri adalah dengan hidup lajang. Namun pilihan ini hampir tidak mungkin untuk ukuran Indonesia yang $80 \%$ masih berideologi pedesaan (tradisional). Masyarakat pasti akan menghujaninya dengan berbagai stigma. Kalau memilih kawin perempuan senang maupun tidak, perempuan harus menjadi ibu rumah tangga dengan beban yang sangat berat seperti yang terurai di awal tulisan ini, terlepas dari apakah dia menjadi isteri dari suami yang berpenghasilan berlebih, pas-pasan atau pengangguran. Artinya pilihan yang tersedia bagi perempuan seperti tidak ada pilihan, karena pilihan semuanya samasama berat. Di Indonesia perkawinan adalah sebuah keharusan, dan bila dia kawin dia harus menjadi ibu rumah tangga yang diperlakukan bukan dengan jargon separate but equal tapi dengan separate and unequal. ${ }^{15}$

\section{IV.Alienasi, Kultur dan Masyarakat.}

Sesuai dengan konsep Schacht tentang alienasi kultur dan masyarakat, penulis melihat bahwa perempuan yang tidak mempunyai pilihan karena himpitan pembakuan peran gender merasa termarjinalkan dari kehidupan dan selanjutnya menutup diri dari dunia luar. Akibatnya akan terjadi anomie, yaitu perasaan bingung dan tidak menentu. Disatu sisi perempuan sebagai manusia ingin berkembang, mempunyai kebebasan untuk mengontrol dan menentukan nasib sendiri. Di sisi lain, perempuan ingin hidup diterima di tengah masyarakat, dianggap sebagai orang yang baik dan mendapatkan penghargaan. Namun dengan pembakuan peran gender yang sedemikian, perempuan tidak bisa mendapatkan keduanya. Segala yang dilakukan (dalam lingkup rumah tangga) harus dengan "izin" dari suaminya tanpa mendapatkan izin tindakannya tidak syah. Bahkan menjalankan ibadah pun bila tidak mendapat izin dia tidak boleh melakukannya

\footnotetext{
15 Sullivan, N. (1991) "Gender and Politics in Indonesia" in Maila Stivens Why Gender Matters in Souteash Asian Politics. Monash Papers on Southeast Asia.
} 
Perempuan sebagai manusia, bila terampas harkat dan martabatnya sebagai makhluk bebas tentu akan merasa bingung dan hidupnya tidak menentu dia merasa teralienasi disebabkan oleh konstruksi sosial yang menghimpitnya.

\section{E. Penutup}

Tulisan ini adalah pemikiran awal yang tentunya membutuhkan penelitian yang lebih cermat dan jeli bila kemudian dijadikan sebuh teori. Namun penulis yakin fenomena ini perlu mendapat perhatian yang mendalam dari para ahli ilmu sosial terutama pemerhati perempuan, khususnya perempuan Islam di Indonesia. Ahli ilmu sosial memang diharapkan untuk senantiasa menguak fenomena eksploitasi manusia atas manusia lain seperti perbudakan, perburuhan, kemiskinan struktural termasuk eksploitasi terhadap perempuan terlepas dari apakah buidak, buruh, si miskin atau perempuan yang menjalani tidak mempermalahkan hal tersebut.

\section{Daftar Pustaka}

Abraham, F.M. (1982) Modern Sociological Theory: An Introduction. London, Oxford University Press.

Al Bagdadi, Abdurrahman (1991) Emansipasi Adakah dalam Islam: Suatu Tinjauan Syari'at Islam tentang Kehidupan Wanita, Gema Insani Press, Jakarta.

Al Jandul, Sa’id Abdul Aziz (1991) Wanita dibawah Naungan Islam. CV. Fidaus, Jakarta.

Asy-Syantuh, Khalid Ahmad (1993) Pendidikan Anak Putri dalam Keluarga Muslim. Pustaka Al-Kautsar, Jakarta.

Dobosh, E. dan Dobosh, . P. R. (1995) "Wives : The "appropriate" Victims", Victimology, Vol 2 
Foreman, A. (1977) Femininity as Alienation: Women and Family in Marxism and Psychoanalysis. London, Pluto.

Gove R. W., and J. F. Tudor (1975) "Adult sex role and mental ilness" in Joan Huber Changing Women in a Changing Society, Chicago and London : The University of Chicago Press.

Hemas, G.K.R. (1992) Wanita Indonesia, Konsepsi dan Obsesi, Yogyakarta, Liberty.

Lawang, R.M.Z. (1986) Teori Sosiologi Klasik dan Modern. Terj. Jakarta, PT Gramedia.

Munti, R. B. (1997) "Respon Agama (Islam)terhadap Pembakuan Peran" Penelitian tidak dipublikasikan.

Pagelow, M. (1984) Family Violence. New York, Praeger.

Peg, Terry (2003) “She Works, He Doesn't”, Newsweek 5 / 12 / 2003 Vol 141

Pratt, Geraldine (2003) “Valuing Children”, Gpratta.geog.ubc.ca, Juni 2003.

Rahardjo Y. et al (1986) Wanita Kota jakarta: Kehidupan Keluarga dan Keluarga Berencana, Yogyakarta : Gajah Mada University Press

Sullivan, N. (1991) "Gender and Politics in Indonesia" in Maila Stivens Why Gender Matters in Souteash Asian Politics. Monash Papers on Southeast Asia.

Schwarz, A. (1994) A Nation in Waiting: Indonesia in the 1990s, Sydney, Alen \& Unwin. 